\title{
Organisational Culture and Employee Engagement within the Ghanaian Public Sector
}

\author{
Richard S Brenyah* and Theresa Obuobisa-Darko \\ Department of Administration, Methodist University College Ghana, Accra, Ghana
}

\begin{abstract}
The paper examines the relationship between corporate culture and employee engagement among employees in public sector organisations of Ghana. A review of the relevant literature indicates that corporate culture as a measure of employee engagement especially in the public sector of a developing country in Africa such as Ghana has been given limited research efforts. To address this, the study adopted Handy's cultural framework as limited efforts have been geared toward investigating the effect each of Handy's four pillars of culture has on employee engagement. The multiple regression technique was used to test the hypothesised relationships between the variables in the study. A sample of two hundred and sixty-seven (267) employees was randomly drawn from selected public-sector organisations in Ghana. Findings from the study established that, achievement and support cultures significantly cause employees to be engaged in the public sector of Ghana whilst power culture has a significant, but negative relationship with employee engagement. The relationship between role culture and employee engagement is not significant. The study recommends that, in order for the skilled employees in the Ghanaian public sector organisations to be highly engaged, management of such organisations should increase the extent of achievement and support cultures and minimize the extent of power culture while paying only a little attention to role culture.
\end{abstract}

Keywords: Organisational culture; Support culture; Power culture; Role culture; Achievement culture; Employee engagement; Public sector organisation

\section{Introduction}

Culture is one of the important sources of competitive advantage and will always be, as it affects organisational behaviour and corporate performance positively or negatively [1]. It is important for managers, consultants and academics to broadly accept this fact (Mckenzie). The culture of an organisation affects employee satisfaction and commitment [2], performance [3] as well as employee engagement. Cole [4] believes that the purpose and goals of any organisation influence its culture and significantly affect employee morale, retention and their level of engagement. It is not just about being a good employer, but about having an employee committed to the vision, mission and the strategy of the organisation, and possessing the will and means to constantly contribute in making these a reality. Effective corporate culture cause high levels of engagement and this translates into high productivity [5].

A high level of employee engagement (EE) is vital to the organization [6]. Engaged employees are dedicated to the work, work with vigour and get absorbed in the work they do. Several factors like leader behaviour and availability of resources affect EE. However, the literature, mostly from developed countries attest to the key role played by culture towards increased employee engagement Creating a culture that is conducive in the Ghanaian public sector for EE is therefore imperative.

Both research findings and observations of successful companies have established a direct link between strong corporate cultures, high employee commitment and engagement [7,8]. According to Mckenzie, the concept of organisational culture covers every aspect of an organisational life and affects everything an organisation does, but unfortunately has not been given the needed research effort required. Looking through the literature, it was evident that progress has been made in related areas such as organisational socialisation $[9,10]$, organisational change [5,8] organisational climate [11], organisational leadership [12] but with few research focusing on culture and employee engagement in developing countries like Ghana. O'Reilly [13] confirms that little attention has been given to the issue of organisational culture in relation to employee engagement. Culture in state owned organisations are usually portrayed in a taken-for-granted manner [14]. Again, one limitation of previous research is that organisational culture has been regarded in a general sense and little attention has been directed at differentiating between the different kinds of cultures within a functioning organisation $[15,16]$.

Most studies on EE have been carried out in developed countries such as The Netherlands [17], India [18] and Greece [19] among others. In addition, participants in these studies were not from the public sector. Given that public sector organisations in Ghana contribute a great deal towards the socioeconomic development of the country and the role engaged employees play in organisational success, it is unfortunately that not much research has been carried out with focus on these. Manuh et al. [14] indicated that the public sector of the economy faces a great challenge in maintaining a highly engaged workforce. According to Puplampu, majority of the public-sector workers in Ghana only see their jobs as a means to an end which is a reflection of low level of EE. A study conducted by Turkson [20] revealed that the Ghanaian economy would have attained a developed economic status if public sector employees were highly committed and engaged just like the private sector.

Literature confirms a relationship between organisational culture and $\mathrm{EE}[21,22]$. It is in view of this that the present study attempts to

*Corresponding author: Richard S. Brenyah, Department of Administration, Methodist University College Ghana, Accra, Ghana, Tel: + 233302312980 ; Email: brichie80@yahoo.com

Received December 04, 2017; Accepted December 19, 2017; Published December 27,2017

Citation: Brenyah RS, Obuobisa-Darko T (2017) Organisational Culture and Employee Engagement within the Ghanaian Public Sector. Review Pub Administration Manag 5: 233. doi:10.4172/2315-7844.1000233

Copyright: (c) 2017 Brenyah RS, et al. This is an open-access article distributed under the terms of the Creative Commons Attribution License, which permits unrestricted use, distribution, and reproduction in any medium, provided the original author and source are credited. 
investigate the relationship between organisational culture and EE in the Ghanaian public sector. The study hopes to add to literature on the effect of the various pillars of culture on EE among public sector employees in developing countries using the structural model of organisational culture developed by Harrison [23] and modified by Handy [24]. The remaining parts of the paper therefore capture the following: theoretical and empirical literature, methodology, data analyses, results, discussions, conclusions and implications of the study.

\section{Literature Review}

\section{Organisational culture}

Organisational culture has been defined severally by different authors and in most of these the common fact or denominator is the idea that culture is something that is shared among members of an organisation. Organisational culture according to Suharti and Suliyan [22] is a system of values held and conducted by members of an organisation which distinguishes the organisation form other organisations. It is a pattern of basic assumptions, invented, discovered or developed by a given group as it learns to cope with its problems of external adaptation and internal integration that have worked well enough to be considered valid and therefore is to be taught to new members as the correct way to perceive, think and feel in relation to those problems $[8,25]$. Different models of culture exist in literature. These include Cooper's [26] cultural model; Cammazzi's cultural model, Schein's [8] cognitive levels of culture and Deal and Kennedy's [27] Cultural Parameters. Among these, the more prominent model is Handy's [24] cultural framework which identifies four kinds of organisational culture as: Power culture, Role culture, Achievement culture and Support culture.

\section{Power culture}

Power culture is a type of culture which is characterised by control and power emanating from the central leader and usually operates informally with few rules and procedures. Handy [24] noted that this type of power suits the figurehead and can result in what Cooper [26] identified as power distance where there is high willingness on the part of less powerful individuals in a group to accept the unequal distribution of power without question and to regard it as normal. Role Culture is a type of culture which is characterised by bureaucracy as work is coordinated by a manager or small number of managers at the top. In this culture, roles are seen to be more important than the people who fill them and people have clearly delegated authorities within a highly defined structure. Achievement culture is focused on the mission of the organisation and on completing the job. This engenders a strong sense of purpose in members which tend to override all other considerations. Priority is given to ends rather than means and individual expertise are highly valued. Support culture is a type of culture which is consensual with limited management control. According to Schein [8], support culture is one in which people contribute out of a sense of commitment and solidarity. Relationships are characterised by mutuality and trust and the organisation exists primarily to serve the needs of its members. In a support cultured organisation, individuals are expected to influence each other through examples and assistance.

\section{Employee engagement (EE)}

$\mathrm{EE}$ is an important issue in modern organisation as it is related to organisational performance. Several researchers [28-30] in their research confirmed the positive consequence that employee engagement has on employee task performance. This may be because engaged employees are likely to remain with their organisation $[17,28,31,32]$, and hence better performance [20], will continue to be achieved within the organisation (Markos \& Sridevi). The definition of employee engagement continues to evolve [33]. Kahn one of the first to publish papers on employee engagement, defined it as 'the simultaneous expression and employment of a person's "preferred self" in their work task, thereby promoting connections to work and to others, personal presence (physical, cognitive and emotional) and active, full role performances' (p. 700). As a result, engaged employees put much efforts into the work they perform for the reason that they identify with it. It involves "a positive, fulfilling, affective-motivational state of work related well-being that can be seen as the antidote of job burnout" [19]. Thus, employee engagement is more than just the investment of a single aspect of the self; it represents an investment of multiple dimensions like physical, emotional, and cognitive (Vigoda-Gadot).

Schaufeli et al. [17] on their part explained employee engagement as 'a positive fulfilling work-related state of mind that is characterised by vigor, dedication and absorption' [17]. Vigour reflects the drive to expend effort in the work one does, ability to remain steadfast in the wake of job related obstacles and a demonstration of high levels of energy. Dedication is characterized by a sense of significance, enthusiasm, inspiration, pride, and challenge. Absorption is characterized by being deeply engrossed and fully concentrates and in the work one does in a way that time passes swiftly, and one has difficulties with detaching oneself from work. Thus, engaged employees exhibit vigour, dedication and absorption, are committed, dedicated and invest their work roles cognitively, psychologically and behaviourally. Having engaged employees in an organisation is of much interest in recent times. Indeed, an engaged, positive workforce can "make or break" an organization (Lockwood). Employee engagement is noted for its positive outcomes [19] such as increase profit (Piersol), high levels of performance, and a source of competitive advantage. Again, when employees are engaged, everyone benefits. This is because the employees see themselves as part of the organisation and use their talents, skills, and also develop fruitful relations which would increase their efficiency Taking into account the benefits of engaged employees, it is clear that engagement matters and therefore the need to identify how the acceptable ways of doing things in an organisation, the culture, affect the employees' level of engagement.

\section{Organisational culture and employee engagement}

Several studies in developed countries have confirmed a link between organisational culture and employee engagement. The relationship between organisational culture and EE can be explained from the social exchange theory (SET) perspective. According to the theory, social behaviour is the result of an exchange process. In his seminal writing on social exchange, Homans [34] noted that "Social behaviour is an exchange of goods. Thus, when employees perceive the culture of the organisation allows them to have good relationship with other members within the organisation, where they have the needed support and power among others, they tend to give their all, be dedicated and work with vigour.

In a cross-sectional study of employees in public accounting firms in Pakistan, Sheridan [35] found that accounting firms got their workers committed and engaged in their jobs not because of the nature of attractive incentives given them but because their organisational culture was compatible with the employees' values. Schein [8] established that when the culture of an organisation is not appreciated by its members, the employees develop a high tendency to quit than to stay. Allen [36] in his Person-Environment (P-E) Fit Model established that organisations that develop cultures that are compatible with the values of their members are able to retain and engage a higher percentage of their key employees. Based on the above we hypothesise that: 
H1: Organisational culture as a whole will have a positive and significant effect on employee engagement.

Allen [36] in a study to measure the effect of power and authority on employee behaviour at work used a sample of 1,720 workers in selected public corporations in South Korea and found that when the level of power and authority within these firms was high, lower level employees usually felt intimidated by their superiors and this resulted in too much tensions within the organistaion. Therefore, the intention to stay was limited. Also, Cooke and Lafferty [37] in a cross-sectional study of employees among health service organisations in New Jersey found that when power was overemphasized within these institutions, the needs of persons in high positions were satisfied at the expense of low level employees who to a large extent undertook the operational activities. In such high power cultured organisations, such low-level workers feel demotivated and this results in a higher intention to quit and therefore exhibit a low level of engagement.

\section{Based on the above, we hypothesize that:}

H2: Power culture will have a significant and negative effect on employee engagement.

Glaser sampled 190 employees among selected telecommunication companies in Malaysia and found that when proper and effective job analysis was conducted within an organisation in the telecommunication industry such that roles and responsibilities of workers, especially those of junior members and new recruits were clearly defined, the extent of ambiguities in roles were limited and this lead to effective job performance which consequently engaged their employees at work for the maximum period.

Based on the above, we hypothesize that:

H3: Role culture will have a positive and significant effect on employee engagement.

Findings by Gordon [38] established that if employees perceive no support from their organisation in terms of the provision of right equipment and tools relevant to their jobs, they mostly feel reluctant to perform and consequently separate with the organisation. Hagan [39] did a qualitative study on 'training and employee commitment among 120 sampled workers from selected commercial banks in Accra, Ghana' and found that after training, if the trained workers are not given the kind of support needed to apply the knowledge and skills acquired in relevant areas of the organisation, they may feel demotivated and consequently have a strong intention to quit the organisation. $\mathrm{He}$ established that, even if such employees decide to stay, it might probably be as a result to the lack of job opportunities in that market and as such their commitment and engagement to the organisation would be a challenge.

In relation to the above, we hypothesize that:

H4: Support culture will have a positive and significant effect on employee engagement.

A study by Barkman et al. [35] among academic staff of selected state-owned universities in Pakistan found that these universities had a high sense of achievement and this contributed to the high levels of employee retention and engagement these institutions have achieved over the years. Schneider [11] established that approximately 95\% of the teaching staff among Canadian universities were motivated to stay in their universities largely because of the extent to which goals and objectives were clearly defined both at the departmental and organisational levels.
Based on the above studies, we hypothesize that:

H5: Achievement culture will have a positive and significant effect on employee engagement.

\section{Research Design}

\section{Research approach}

The study adopts the quantitative approach using the correlational survey design in data collection and analysis. According to Creswell and Creswell [40] correlations design seeks to establish the relationship among several variables in a study. Also, Lomax [41] posits that quantitative studies guard against biases and alternative explanations and also consider generalizability and replication of findings.

The correlational survey method is appropriate for this study because Gyensare [42] explains that correlational surveys examine the extent to which differences in one variable are related to the differences in one or more other variables and thus examines and explains the relationship among variables in a study. This research design was employed for the study because the study aims to predict the relationship between organizational culture and employee engagement within the Ghanaian public sector.

\section{Measures and Data Collection Method}

Due to the fact that UWES has been validated across several cultures, researchers like Storm and Rothmann [43] have acknowledged that it can be used as an unbiased instrument to assess work engagement because the three-factor model has proven to be valid across nations. The Utrecht Work Engagement Scale (UWES) developed by Schaufeli et al. [17], is used to measure employee engagement level in this study. The instrument consists of 17 items, which are scored on a 7-point frequency scale, ranging from Never (0) to Daily (6). The measure has three sub-scales, namely vigour, dedication, and absorption [17]. A typical item for Vigour is: "When I get up in the morning, I feel like going to work." A typical item for Dedication is: "My job inspires me." A typical item for Absorption is: "I am immersed in my work." A high score indicates high levels of engagement.

Organizational culture is measured using the Organisational Culture Assessment Tool (OCAT) originally developed by Harrison [23] and modified by Harrison and Stoke's [44]. This research instrument has four subscales- power culture, support culture, achievement culture and role culture [44]. A typical item in the power culture subscale is: "Members of this organisation are always expected to give first priority to meeting the needs and demands of their supervisors and those at high-levels". A typical item in the support culture subscale is: "In this organization, people are directed and influenced by their own desire to be accepted by others and to be good members of their work group". A typical item in the achievement subscale is: "In this organization, people are directed and influenced by their own commitment to achieve the goals of the organization". A typical item in the role culture subscale is: "In this organization, people are directed and influenced by the systems, rules and procedures that prescribe what people should do and the right way of doing it. The instrument is rated on a five-point likert scale (ranging from ' $1=$ Strongly Disagreed through to $5=$ Strongly Agreed').

\section{Data Analyses}

In analyzing the data, the simple regression and the multiple regression techniques were used. The multiple regression technique is a data analysis technique that allows researchers to measure the effect of 
two or more predictor variables on one outcome or dependent variable in a single model whilst the simple regression model allows researchers to measure the effect of one predictor variable on one outcome variable in a study [41]. The use of the multiple regression is appropriate for this study as it adequately measures the effect each of the various predictor variables (power culture, role culture, achievement culture and support culture) has on the dependent variable (employee engagement) and the simple regression technique is appropriate for the study as it adequately measures the effect of the composite variable (organizational culture) as the predictor variable on employee engagement as the outcome variable. Prior to the multiple regression analysis, the Pearson Correlations was used to test for the statistical significance of the relationship between the variables in the study. This made the data viable enough for the multiple regression analysis. The results of the study are presented in Tables and discussed appropriately.

\section{Results}

The results of analysis of the descriptive statistics of the continuous variables in Table 1 indicate that the mean distribution of power culture, role culture, achievement culture, support culture and employee retention are $1.8556,2.0486,2.0833,2.0479$ and 2.1403 respectively. Comparing the means, it is shown that respondents would be more engaged to their organization when the culture adopted is more of achievement than the others. Standard deviations are close to 1 ; hence the data is valid.

Table 2 shows the correlations between each pair of variables. The results indicate that correlations between each pair of variables are below 0.05; hence the correlations between the variables in the study are statistically significant at $95 \%$ significant level. Also, the Pearson ' $r$ ' indicates weak linear relationships between the independent variables

\begin{tabular}{|c|c|c|c|c|c|}
\hline Variables & $\mathbf{N}$ & Mean & Std. deviation & Minimum & Maximum \\
\hline Power culture & 267 & 1.8427 & 0.61451 & 1.00 & 4.00 \\
\hline Role culture & 267 & 1.9688 & 0.64733 & 1.00 & 4.00 \\
\hline $\begin{array}{l}\text { Achievement } \\
\text { culture }\end{array}$ & 267 & 2.0612 & 0.67446 & 1.00 & 4.00 \\
\hline Support culture & 267 & 1.9688 & 0.66200 & 1.00 & 5.00 \\
\hline $\begin{array}{l}\text { Employee } \\
\text { engagement }\end{array}$ & 267 & 3.5265 & 0.88835 & 1.71 & 6.18 \\
\hline
\end{tabular}

Table 1: Descriptive statistics of continuous variables. in the study. Moreover, the Pearson ' $r$ ' indicates positive correlations between the dependent variable (employee engagement) and the independent variables - role culture, support culture and achievement culture except for power culture that shows an inverse correlation with employee engagement.

According to Gaur and Gaur, the error of multicollinearity occurs when any pair of independent variables are highly correlated ( $>0.05)$ Table 3 shows the level of correlations between the independent variables. Results however show that correlations between the variables are less than 0.05 . This indicates the non-existent of multicollinearity among the variables, thereby making the data reliable.

The results in Table 4 indicate the means ( $\mathrm{M}$ ) and standard deviations (SD) for the various facets of culture and employee engagement. The Pearson ' $r$ ' correlation indicates that there is a moderate positive correlation between culture and employee engagement $(r=0.627$, $\mathrm{P}=0.000$ ). This means that when employees believe and share in the culture of their organisation, they become engaged to their jobs and the organization and express a high desire to stay rather than quit their jobs, other things being equal.

\section{Discussion of Findings}

Multiple regression analyses carried out to test the hypothesized relationships and effects between the different kinds of culture and employee engagement are summarized in Table 5. The results of the analyses show that achievement culture $(\beta=0.407, \mathrm{p}<0.05)$ and support culture $(\beta=0.312, p<0.05)$ have significant and positive effect on employee engagement whilst power culture $(\beta=-0.210, p<0.05)$ showed a negative and significant effect on employee engagement. However, role culture $(\beta=0.116, p>0.05)$ showed an insignificant relationship with employee engagement, hence its effect cannot be accepted as reliable.

The findings of the study provide support for $\mathrm{H} 1$ which posits a negative and significant effect between power culture and employee engagement. This means when the extent of power within the organisation is high or over emphasised, the extent to which employees are engaged to their organisation will reduce. These results are consistent with the findings of Cooke and Lafferty [37] and Enz which established a significant but negative relationship between power culture and employee engagement. They found that in a high power cultured environment, lower level employees usually feel intimidated

\begin{tabular}{|c|c|c|c|c|c|c|}
\hline Variables & \multicolumn{2}{|c|}{ Power culture } & \multirow{2}{*}{$\begin{array}{c}\text { Role culture } \\
0.197^{* *}\end{array}$} & \multirow{2}{*}{$\begin{array}{c}\text { Achievement culture } \\
0.379^{* *}\end{array}$} & \multirow{2}{*}{$\begin{array}{c}\text { Support culture } \\
0.219^{* *}\end{array}$} & \multirow{2}{*}{$\begin{array}{c}\begin{array}{c}\text { Employee } \\
\text { Engagement }\end{array} \\
-0.112\end{array}$} \\
\hline \multirow{3}{*}{ Power culture } & Pearson Correlation & 1 & & & & \\
\hline & Sig. & - & 0.001 & 0.000 & 0.000 & 0.024 \\
\hline & $\mathrm{N}$ & 267 & 267 & 267 & 267 & 267 \\
\hline \multirow{3}{*}{ Role culture } & Pearson Correlation & $0.197^{* *}$ & 1 & $0.306^{* *}$ & 0.046 & 0.090 \\
\hline & Sig. & 0.001 & - & 0.000 & 0.027 & 0.041 \\
\hline & $\mathrm{N}$ & 267 & 267 & 267 & 267 & 267 \\
\hline \multirow{3}{*}{ Achievement culture } & Pearson Correlation & $0.379^{* *}$ & $0.306^{* *}$ & 1 & $0.327^{* *}$ & 0.191 \\
\hline & Sig. & 0.000 & 0.000 & - & 0.000 & 0.040 \\
\hline & $N$ & 267 & 267 & 267 & 267 & 267 \\
\hline \multirow{3}{*}{ Support culture } & Pearson Correlation & $0.219^{* *}$ & 0.046 & $0.327^{* *}$ & 1 & 0.157 \\
\hline & Sig. & 0.000 & 0.027 & 0.000 & - & 0.017 \\
\hline & $\mathrm{N}$ & 267 & 267 & 267 & 267 & 267 \\
\hline \multirow{3}{*}{$\begin{array}{c}\text { Employee } \\
\text { Engagement }\end{array}$} & Pearson Correlation & -0.112 & 0.090 & 0.191 & 0.157 & 1 \\
\hline & Sig. & 0.024 & 0.041 & 0.040 & 0.017 & - \\
\hline & $\mathrm{N}$ & 267 & 267 & 267 & 267 & 267 \\
\hline
\end{tabular}

Table 2: Correlations between variables. 


\begin{tabular}{|c|c|c|c|c|c|c|}
\hline Variables & \multicolumn{2}{|c|}{ Role culture } & Power culture & Support culture & Achievement culture & Durbin-Watson \\
\hline \multirow{4}{*}{ Correlations } & Role culture & 1.000 & - & - & - & - \\
\hline & Power culture & 0.041 & 1.000 & - & - & - \\
\hline & Support culture & 0.030 & 0.032 & 1.000 & - & - \\
\hline & Achievement culture & 0.023 & 0.003 & 0.015 & 1.000 & 1.819 \\
\hline
\end{tabular}

Table 3: Correlations matrix showing the non-existent of multicollinearity between the independent variables.

\begin{tabular}{|c|c|c|c|c|}
\hline Variable & M & SD & N & R \\
\hline Power culture & 1.8427 & 0.61451 & 267 & $0.627^{\star *}$ \\
\hline Role culture & 1.9688 & 0.64733 & 267 & - \\
\hline Achievement culture & 2.0612 & 0.67446 & 267 & - \\
\hline Support culture & 1.9688 & 0.66200 & - & - \\
\hline Employee retention & 3.5265 & 0.88835 & 267 & - \\
\hline
\end{tabular}

Table 4: Summary of correlation between organizational culture and employee engagement

\begin{tabular}{|c|c|c|c|c|c|c|c|c|c|c|c|}
\hline \multicolumn{4}{|c|}{ Unstandardized coefficients } & $\begin{array}{l}\text { Standardised } \\
\text { Coefficients }\end{array}$ & $\mathbf{T}$ & $\mathbf{P}$ & $\mathbf{F}$ & $\mathbf{R}$ & R Square & $\begin{array}{l}\text { Adjusted R } \\
\text { Square }\end{array}$ & VIF \\
\hline & Model & B & Std. Error & \multicolumn{8}{|c|}{ Bet } \\
\hline \multirow{5}{*}{1} & (Constant) & 1.378 & 0.261 & - & 5.271 & 0.000 & 11.063 & 0.627 & 0.393 & 0.131 & - \\
\hline & Power culture & -0.181 & 0.065 & -0.210 & -2.790 & 0.006 & - & - & - & - & 1.282 \\
\hline & Role culture & 0.101 & 0.057 & 0.116 & 1.777 & 0.077 & - & - & - & - & 1.111 \\
\hline & Achievement culture & 0.339 & 0.063 & 0.407 & 5.399 & 0.000 & - & - & - & - & 1.508 \\
\hline & Support culture & 0.178 & 0.056 & 0.312 & 3.189 & 0.002 & - & - & - & - & 1.238 \\
\hline
\end{tabular}

Source: Fieldwork, 2017

Table 5: Multiple regression showing the effect of each of the four pillars of culture on employee engagement.

\begin{tabular}{|c|c|c|c|c|c|c|c|c|c|c|c|c|c|}
\hline & Model & $\begin{array}{l}\text { Unstandardized } \\
\text { coefficients }\end{array}$ & \multirow{2}{*}{\multicolumn{2}{|c|}{$\begin{array}{c}\begin{array}{c}\text { Standardised } \\
\text { coefficients }\end{array} \\
\text { Std. error }\end{array}$}} & $\mathbf{T}$ & $\mathbf{P}$ & $\mathbf{F}$ & $\mathbf{R}$ & \multicolumn{2}{|c|}{ R Square } & \multicolumn{2}{|c|}{ Adjusted R Square } & VIF \\
\hline \multicolumn{3}{|c|}{ B } & & & \multicolumn{9}{|c|}{ Beta } \\
\hline \multirow[t]{2}{*}{1} & Constant & 1.031 & 0.260 & & 3.960 & & 000 & & 11.027 & 0.598 & 0.356 & 0.144 & - \\
\hline & Organisational Culture & 0.579 & 0.088 & 0.403 & 6.574 & & 000 & & - & - & - & - & - \\
\hline
\end{tabular}

Table 6: Simple regression showing the impact of organisational culture on employee engagement.

and as such show a higher intention to quit the organization at the initial stages. They added that, the few employees who may wish to stay in such rigid environment only do so because they do not perceive any job opportunities elsewhere. As a result, such employees exhibit low level of commitment which consequently affects their level of engagement to their jobs and the organization within which they work. The results may be because in a high-power culture, power emanates from the leader [10] and therefore employees do not have much autonomy and are not able to use their discretion. This may explain the reason for this result. Job autonomy has been identified as having a positive relationship with employee engagement $[32,45]$. Employees who assume more autonomy in their work develop a sense of engagement in their work. Thus, where there exists high power culture and therefore not much autonomy, it is likely to have a negative effect on employees' engagement as it is in this study.

The finding also supports $\mathrm{H}_{4}$ which posits that support culture have a positive and significant effect on employee engagement. This result support the findings of Amacost [38]. In organisations where there exists support culture, there is mutual trust between the individuals and the organisation, that is the leaders [44] and this causes employees to be engaged. Trust according to Ugwu et al. [46] explains why employees are willing to go beyond the call of duty in their work with no outstanding reward, a characteristic of an engaged employee. Thus, Macey and Schneider [33] have argued that trust is a prerequisite to engagement and that the presence of a supportive and trusting work environment is a vital factor for enhancing employee engagement. It can thus be deduced that when there exist support culture and as a result there is trust, employees get engaged, thus explaining the results of this study.

Results from the study showed that achievement culture has a positive and significant effect on employee engagement. The achievement culture engenders a strong sense of purpose in employees. According to Harrison [47], in an achievement oriented organisation, rule and regulations are not allowed to get in the way of doing work. As a result, employees in such organisations are allowed to use their discretion when working. Findings from research show that employees who have discretion at the work place show high levels of enthusiasm, a characteristic of an engaged employee and lower levels of fatigue [48]. It can thus be inferred that when there exists achievement culture, employees are allowed to use their discretion which increase their level of engagement, thus achievement culture positively affects employee engagement.

The results of the analyses in Table 6 which is a simple regression model showing the effect of the composite variable (organisational culture) on employee engagement indicate that organisational culture $(\beta=0.403, p<0.05)$ shows a significant and positive effect on employee engagement and this supports $\mathrm{H} 5$ which posits a significant and positive effect of organisational culture on employee engagement. This finding is consistent with the findings of Allen [36] which demonstrated a 
significant and positive effect between organisational culture and employee engagement. Allen [36] found that when the members of an organisation share in the values and assumptions around which their organisations grow, they become highly committed to their jobs. Senior and Fleming [1] affirmed the position of Allen [36] by emphasizing that 'effective corporate culture engages employees at the fundamental level, and transmit that engagement into high commitment and productivity (p.58)'. This could probably be as a result of managers and organisational leaders transmitting the culture around which their organisation grows into their employees at the initial stages of their work life; thereby requiring employees to share in the culture.

\section{Conclusion}

The following conclusion are drawn from the study and appropriate recommendations are made:

- Organisational culture contributes moderately to the extent of variations in employee engagement among Ghanaian public organisations ( $\mathrm{R}$ Square $=0.356$ ). That is organisational culture account for approximately $36 \%$ of variations in the extent of employee engagement among these public-sector organisations.

- The issue of corporate culture plays a significant role in engaging employees working in the Ghanaian public sector organisations.

- There were differences between the four kinds of organisational culture-power role, support and achievement cultures and each, except role culture has a significant effect on employee engagement in the Ghanaian public sector.

- Achievement culture and support culture have positive and significant influence on employee engagement with achievement culture having the greatest influence $(\beta=0.407)$, followed by support culture $(\beta=0.312)$.

- Though role culture has a positive relationship with employee engagement in the Ghanaian public sector, $(\beta=0.116)$, it is not significant $(\mathrm{p}>0.05)$, making its parameter estimate is unreliable.

\section{Implications to Policy Makers}

The study has implications to policy makers of the various publicsector organisations in the following ways:

- The authorities and policy makers of public sector organisations need to consider the issue of organisational culture as key factor that engages their employees at work and hence they should have it in mind when designing/developing the policy framework of their organisation.

- Power culture has a significant and negative effect on employee engagement among Ghanaian public-sector organisations and this makes it necessary for authorities and policy makers of these institutions to take measures to minimize the extent of power culture which involves control and power emanating from the central leader.

- Based on the research findings, it is imperative for the authorities and policy makers of public sector organizations of Ghana to develop cultures that are well appreciated and consistent with the interest of the employees in order to gain their commitment, retain and engage them for the maximum periods.

\section{Implications to Future Researchers}

Under this section, the researchers have given few suggestions to guide other researchers who may be motivated to conduct further studies on the subject matter:
- Further studies may examine the situation on privately owned organisations in Ghana as this current study focused solely on public organisations. This would enable researchers find out whether or not the type of ownership would influence the findings in one way or the other.

- Further researchers may also extend the issue beyond the borders of Ghana to find out whether economic conditions in other countries may also influence the findings in one way or the other.

\section{References}

1. Senior B, Fleming J (2006) Organisational change (3rd edn). New Jersey, NJ: Prentice Hall, USA.

2. Schein E (2009) Transforming cultures (2nd edn). San Francisco, CA: JosseyBass, USA.

3. Ahmed M, Shafiq S (2014) The impact of organizational culture on organizational performance: A case study on telecom sector. Global J Manage Bus Res 14 $1-11$.

4. Cole GA (2012) Organisational behaviour (2nd edn.). New York, NY: Continuum, USA

5. Kotter JP, Heskett JI (1992) Corporate culture and performance. New York, NY: Free press, USA.

6. Richman A, Civian J, Shannon L, Hill J, Brennan R (2008) The relationship of perceived flexibility, supportive work-life policies, and use of formal flexible arrangements and occasional flexibility to employee engagement and expected retention. Commun Work Fam 11: 183-197.

7. Denison DR (2010) Using corporate culture to enhance employee commitment. New York, NY: John Wiley and Sons, USA.

8. Schein EH (2001) How culture forms, develops and changes. Pers Manage Rev 62: 454-512.

9. Chatman JA (2001) Matching people and organizations: Selection and socialization in public accounting firms. Admin Sci Quart 36: 459-484.

10. Van Maanen J, Schein E (2002) Towards a theory of organizational socialization Organ Behav 11: 209-264.

11. Schneider WE (2009) The reengineering alternative: A plan for making you current culture work. Bur Ridge, H: Irwin Professional Publishing, Inc, USA.

12. Schein E (2002) Organisational culture and leadership (2nd edn). San Francisco, CA: Jossey-Bass, USA.

13. O'Reilly C (2008) Corporations, culture and commitment: Motivation and social control in organisations. California Manage Rev 31: 9-25.

14. Manuh T, Gariba S, Budu J (2009) Change \& transformation in Ghana's public sector. Oxford: James Currey Ltd, UK.

15. Hansen GS, Wernerfelt N (2009) The determinants of performance: The relative importance of economic and organisational factors. J Strat Manage 10: 399-411.

16. Knowles ED, Morris WM, Chiu CY, Hong YY (2001) Culture and the process of person perception: Evidence for automaticity among East Asians in correcting for situational influences on behaviour. Pers Soc Psychol 27: 1344-1356.

17. Schaufeli WB, Bakker AB (2004) Job demands, job resources and their relationship with burnout and engagement: A multi-sample study. J Organ Behavi, 25: 293-315.

18. Ghosh P, Rai A, Singh A (2016) Support at work to fuel engagement: a study of employees of Indian banking sector. Rev Integr Bus Econ Rese 5: 1-10.

19. Xanthopoulou D, Bakker AB, Demerouti E, Schaufeli WB (2009) Work engagement and financial returns: A diary study on the role of job and personal resources. J Occup Organ Psychol 82: 183-200.

20. Turkson G (2012) Culture and organisational effectiveness among tertiary Ghana Polytechnics. J Bus Manage 31: 434-446.

21. Naidoo P, Martins N (2014) Investigating the relationship between organizational culture and work engagement. Probl Perspect Manage 12: 432-440.

22. Suharti L, Suliyanto D (2012) The effects of organizational culture and leadership style toward employee engagement and their impacts toward employee loyalty. World Rev Bus Res 2: 128-139. 
Citation: Brenyah RS, Obuobisa-Darko T (2017) Organisational Culture and Employee Engagement within the Ghanaian Public Sector. Review Pub Administration Manag 5: 233. doi:10.4172/2315-7844.1000233

Page 7 of 7

23. Harrison R (1972) Understanding organisational character. Harvard Bus Rev 5: $119-129$.

24. Handy CB (1987) Understanding organisations (3rd edn) Harmondsworth, Penguin Books, UK.

25. Megginson LC, Mosley DC, Petri PH (2006) Management concepts and applications. New York, NY: Harper \& Row, USA.

26. Cooper CL (1983) Culture's consequences: International differences in work related values. Beverly Hills, CA: Sage Publications, USA.

27. Deal TE, Kennedy AA (2000) The rites and rituals of corporate life (3rd edn). London: Penguin, UK.

28. Alfes K, Truss C, Soane EC, Rees C, Gatenby M (2013) The relationship between line manager behaviour, perceived HRM practices, and individual performance: Examining the mediating role of engagement. Hum Resour Manage 52: 839-859.

29. Anitha $J$ (2014) Determinants of employee engagement and their impact on employee performance. Int J Prod Perf Manage 63: 308-323.

30. Bandura RP, Lyons PR (2014) Situations-vacant fall where employees are engaged. Int Hum Resour Manage Digest 22: 22-25.

31. Harter JK, Schmidt FL, Hayes TL (2002) Business-unit-level relationship between employee satisfaction, employee engagement, and business outcomes: a meta-analysis. J Appl Psychol 87: 268-279.

32. Saks AM (2006) Antecedents and consequences of employee engagement. J Manage Psychol 21: 600-619.

33. Macey WH, Schneider B (2008) The meaning of employee engagement. Ind Org Psychol 1: 3-30.

34. Homans GC (1958) Social behaviour as exchange. Am J Sociol 63: 597-606.

35. Barkman A, Sheridan JE, Peters LH (2002) Survival models of professional staff retention in public accounting firms. J Manage Issues 23: 333-356.
36. Allen DG (2010) Retaining talents through culture studying public accounting firms in Pakistan. Organ Psychol 32: 334-346.

37. Cooke RA, Lafferty JC (2007) Organisational culture inventory. Plymouth, MI: Human Synergistics.

38. Gordon GG (2012) Industry determinants of organisational culture. Acad Manage Rev 16: 396-415.

39. Hagan FT (2004) Training and staff retention among manufacturing organisations in Ghana. J Appl Psychol 32: 132-212.

40. Creswell JW (2009) Research design: Qualitative, quantitative and mixed methods approaches (3rd edn).

41. Lomax RG (2007) An introduction to statistical concepts (2nd edn). Mahwah, NJ: Erlbaum, USA.

42. Gyensare MA (2014) Employee turnover intentions: Empirical evidence from savings and loans companies in Ghana. Saabrucken: Lambert Academic Publishing, Germany.

43. Storm K, Rothmann I (2003) A psychometric analysis of the Utrecht work engagement scale in the South African police service. S Afr J Ind Psychol 29 62-70.

44. Harrison R, Stokes G (1992) Diagnosing organisational culture. New York, NY Pfeiffer and company, USA.

45. Shantz A, Alfes K, Truss C, Soane E (2013) The role of employee engagement in the relationship between job design and task performance, citizenship and deviant behaviors. Int J Hum Resour Manage 24: 2608-2627.

46. Ugwu FO, Onyishi IE, Rodríguez-Sánchez AM (2014) Linking organizational trust with employee engagement: The role of psychological empowerment. Pers Rev 43: 377-400.

47. Harrison R (1993) Diagnosing organisational culture: Trainer's manual. Pfeiffer.

48. Saavedra R, Kwun SK (2000) Affective states in job characteristics theory. J Organ Behav 21: 131-146. 